\title{
KOMUNIKIMI PUBLIK NË PERIUDHËN E KARANTINIMIT NË SHQIPËRI SI KOMUNIKIM NË KRIZ̈̈
}

\author{
Arta Sakja* \\ *Fakulteti i Shkencave Shoqërore, Departamenti i Shkencave Politiko-Administrative, \\ Albanian University
}

Adresë kontakti : artasakja@gmail.com

\section{Përmbledhje}

Ky punim trajton komunikimin dhe qasjet e liderëve politikë ndaj pandemisë përgjatë karantinimit të popullsisë për shkak të Covid-19 në Shqipëri në rrjetet sociale duke vëzhguar rrjetet sociale të Edi Rama, Kryeministër i Shqipërisë (PS), Lulzim Basha, kryetar i opozitës (PD.).

Punimi përdor vëzhgimin e drejtpërdrejtë dhe analizat cilësore si metoda të punës.

Në këtë punim argumentohet fakti së gjatë periudhës së karantinës liderët e ndryshëm politikë në Shqipëri përdorën cilësitë e internetit dhe rrjeteve sociale (komunikimin horizontal, karakterin e përbotshëm, shumëfishimin e menjëhershëm të audiencës, mundësinë për ndërveprim të menjëhershëm, të shpejtë dhe jo të kushtueshëm) për të shpërndarë mesazhet $e$ tyre si edhe për të përforcuar pozicionet e tyre si përfaqësues të mazhorancës apo opozitës. Ky komunikim ka tiparet e komunikimit në krizë dhe vë përballë jo thjesht dy liderë, por dy qasje te ndryshme sipas roleve të aktorëve politikë në përballimin e krizës shëndetësore.

Fjalë çelës: Komunikim në rrjete sociale, komunikim politik, komunikim publik, komunikim $n \ddot{e}$ krizë.

\section{POLITICAL COMMUNICATION DURING THE QUARANTINE IN ALBANIA AS COMMUNICATION IN CRISIS}

\section{Abstract}

This paper addresses the communication and approaches of political leaders to the pandemic during the quarantine of the Albanian population due to Covid-19 delivered on social networks by observing the social networks of Edi Rama, Prime Minister of Albania (SP), Lulzim Basha, Chairman of the Opposition (DP). 
Arta Sakja

The paper uses quantitative and qualitative analysis as research methods.

This paper argues the fact that during the quarantine period different political leaders in Albania use the qualities of the Internet and social networks (horizontal communication, global nature, instant communication, inexpensive interactivity, multiplication of the audience), to deliver their messages as well as to strengthen their positions as political actors, representatives of the majority or the opposition.

This communication has the features of crisis communication and confronts not just two leaders, but two different approaches, according to their political roles in coping with the health crisis.

Keywords: Public communication, political communication, communication in crisis, communication on social media

\section{Hyrje}

Në Shqipëri përdorimi i internetit dhe shërbimeve që ofron ai për qëllime politike është një fenomen me një përhapje të gjerë. "Përdorimi i internetit nga politikanët apo forcat politike ka pësuar një rritje progresive nga viti në vit, ose më saktë nga fushata në fushatë"1

Nga një vështrim i të dhënave që ofrojnë motorët e kërkimit në internet, faqet që pasqyrojnë trafikun dhe tendencat e përdoruesve dhe statistikave të rrjeteve sociale, rezulton se “Shqipëria kishte 2.160 milionë përdorues të internetit në Shqipëri në Dhjetor të vitit 2019, ndërsa penetrimi i tij është 75.1\%. Numërohen 1.408 .000 përdorues të Facebook në 31 dhjetor të vitit 2020”2 shifër që e bën atë rrjetin social më të përdorur në Shqipëri.

Rasti i studiuar nga ky punim është ai i përdorimit të internetiti për qëllime politike në kushtet e karantimit dhe izolimit tërësor të shoqërisë për shkak të virusit COVID-19 nga politikanët shqiptarë duke u fokusuar në dy aktorët kryesorë politikël Edi Rama dhe Lulzim Basha.

Virusi Covid-19 u shfaq fillimisht në Dhjetor të 2019 në kryeqytetin e rajonit Hubei të Kinës, Wuhan. Në fund të shkurtit rastet me COVID-19 u shfaqën në Itali, Iran, Korenë e Jugut, e po rriteshin me shpejtësi, ndaj në javën e parë të muajit Mars, Organizata Botërore e Shëndetësisë u rekomandoi vendeve kufizimet në lëvizjen e njerëzve dhe mbylljen e kufijve. Në Shqipëri, dy rastet e para me COVID-19 u konfirmuan më 8 Mars. Në të njëjtën ditë, qeveria ndaloi të gjitha fluturimet dhe tragetet që vinin nga zona veriore e Italisë deri më 3 prill. Qeveria mbylli fillimisht shkollat për dy javë, urdhëroi ndalimin e të gjithë grupimeve të njerëzve si dhe i kërkoi federatave të sporteve të pezullonin aktivitetet.

Me shpalljen më 11 Mars nga OBSH-ja të COVID-19 pandemi botërore, Këshilli i Ministrave Shqipërisë më 24 mars shpalli gjendjen e fatkeqësisë natyrore për shkak të COVID-19 ku u vendosen masat e jashtëzakoshme të karantimit, që vijoi deri në datën 1 qershor 2020. 
KOMUNIKIMI PUBLIK NË PERIUDHËN E KARANTINIMIT NË SHQIPËRI SI KOMUNIKIM NË KRIZË

Kushtet e karantinimit total rritën vëmendjen qytetare ndaj medias, gjë u shfrytëzua nga politika.

Jo thjesht të dhënat mbi penetrimin e internetit orientuan politikanët drejt përdorimit të tij, por edhe cilësitë e tij dhe të rrjeteve sociale siç janë : komunikimi horizontal, karakteri i përbotshëm, shumëfishimi i menjëhershëm i audiencës, mundësia për ndërveprim të menjëhershëm, të shpejtë dhe jo i kushtueshëm i tyre besohet se ndikuan në këtë përdorim.

Në një vit paraelektoral, politikanët shqiptarë përdorën specifikat e internetit për qëllime të parafushatës, për të kapur pëlqyeshmërinë e qytetarit votues.

\section{Baza teorike e studimit:}

Ky punim mbështetet në përcaktimet teorike mbi komunikimin publik të studiuesit francez Pierre Zemor, sipas të cilit komunikimi publik : «merr forma të ndryshme të lidhura me misionet e institucioneve publike, me qëllim vendosjen e informacionit në dobi të publikut, me qëllim vendosjen e marrëdhënies dhe të dialogut për t'i dhënë publikut një shërbim të pritshëm e të saktë, për të paraqitur shërbimet e ofruara nga administrata, tërësitë territoriale dhe shërbimet e tjera publike, për të bërë të njohura vetë instituticionet, së fundmi për të udhëhequr fushata informimi dhe veprimtari të komunikimit me interes të përgjithshëm, regjistra të cilave u shtohen edhe ata politikë e ata të debatit publik që shoqëron vendimarrjen". ${ }^{3}$

Komunikimi publik kuptohet si një degëzim i komunikimit politik i cili sipas studiuesit australian Brian Mc Nair, kupton "të gjitha format e komunikimit të ndërmara nga politikanët dhe aktorë të tjerë politikë, me qëllim arritjen e disa objektivave specifike që synojnë bindjen e qytetarëve-votues"4 Ndërsa sipas studiuesit Italian Gianpietro Mazzioleni-t ai është: "shkëmbimi dhe përballja e përmbajtjeve të interesave publiko-politike të prodhuara nga sistemi politik, nga media dhe qytetari votues"5

Ky artikull i sheh pozicionet e aktorëve politikë në komunikimin politik nën lentet e studiuesit francez Jacques Gerstlé, sipas të cilit" komunikimi politik frymëzon në fakt strategji dhe qëndrime që ndryshojnë në varësi të pozicioneve të pushtetit dhe situatave të jetuara realisht nga aktorët konkretë në jetën politike". ${ }^{6}$ Ndërsa përsa i përket efektshmërisë dhe të përdorimit të rrjeteve sociale dhe internetit për arsye politike artikullli i referohet sërish Jacques Gerstlé i cili i inkuadron rrjetet sociale në paralele më të gjera duke i pare ato ashtu si : "Rrjetet e mobilizimit, rrjetet e politikave publike, rrjetet e klientelizmit, rrjetet qytetare, rrjetet e shoqërizimit apo ato partiake përbëjnë një formë të aktivitetit politik të bazuar tek jo fizikja, por tek forma shoqërore dhe dëshmojnë për gjithëpranimin e tij ${ }^{7}$ 
Arta Sakja

Komunikimi përgjatë karantinës na çon në një rishikim të komunikimit në krizë të përshkruar nga studiuesi kanadez Xavier Manga cili na njeh edhe me trendet që has ky komunikim nëpërmjet rrjeteve sociale: “ Tre trende dalin nga vëzhgimi i mënyrave të ndryshme të menaxhimit të krizave në epokën e mediave sociale, përkatësisht: 1) njohja e krizës, 2) devijimi i publikut nga subjektet përkatëse dhe 3) rezistenca ndaj kriza nga "strategjia e refuzimit". Ndërsa këto metoda të ndryshme të menaxhimit ndonjëherë mund të mbivendosen me njëratjetrën, sinergjitë që ato mund të krijojnë nganjëherë vendosin ndikuesin në qendër të procesit të tërheqjes së përdoruesve të Internetit" 8

\section{Qëllimi i studimit dhe metodologjia:}

Ky studim u ndal në vëzhgimin e profileve në median sociale Facebook të Edi Ramës Kryeministër i Shqipërisë dhe Lulzim Bashës kryetari i opozitës përgjatë periudhës së pandemisë të shkaktuar nga COVID - 19.

\section{Pyetjet e kërkimit janë :}

1. Si liderët politikë përdorin rrjetet sociale për të tërhequr vëmendjen e publikut në sfidat që ata dëshirojnë të theksojnë?

2. Si i qasen komunikimit publik në rrjetet sociale përfaqësuesit politikë të kaheve të kundërt?

3. A ishte komunikimi nëpërmjet mediave sociale nga politika shqiptare një komunikim në krizë?

\section{IV.Studimi dhe analizimi i të dhënave}

Ky studim u krye përgjatë periudhës 9 Mars - 9 Prill 2020.

U vëzhguan komunikimet publike në rrjetin social Facebook të lidereve te partive dhe ato nw Twitter dhe Instagram më konkretisht Edi Rama (PS) kryeministër dhe Lulzim Basha (PD) lider i opozitës.

\section{Edi Rama ne facebook 9 Mars-9 Prill 2020. ${ }^{9}$}

- Gjithsej 355 postime ne profilin e tij zyrtar ne Facebook.

- Mesatarisht bëri 12 postime në ditë.

- Shfrytëzoi videot në $\mathbf{6 8}$ raste. 
KOMUNIKIMI PUBLIK NË PERIUDHËN E KARANTINIMIT NË SHQIPËRI SI KOMUNIKIM NË KRIZË

- Shfrytëzoi videot live ne $\mathbf{1 4 5}$ raste.

- Shfrytëzoi fotografinë ne $\mathbf{8 8}$ raste.

- Një postim i tij mori mesatarisht 11700 pëlqime. (like)

- Postimet e tij u shpërndanë mesatarisht $\mathbf{5 8 0}$ herë. (share)

- Mesatarisht një postim i tij pati 1375 komente.

\section{Analizë:}

Nëse do të ndërtonim një profil të Edi Ramës në komunikimin publik përgjatë karantimit do të shihnim tendencën për të nxitur zbatimin e masave të ndërmarra nga qeveria për karantinimin e popullsisë duke nënvizuar nivelin e lartë të rrezikshmërisë së pandemisë duke e paraqitur veten më pas si shpëtuesin nga kjo situatë në funksion të ndërtimit të ndërtimit të imazhit pozitiv të tij.

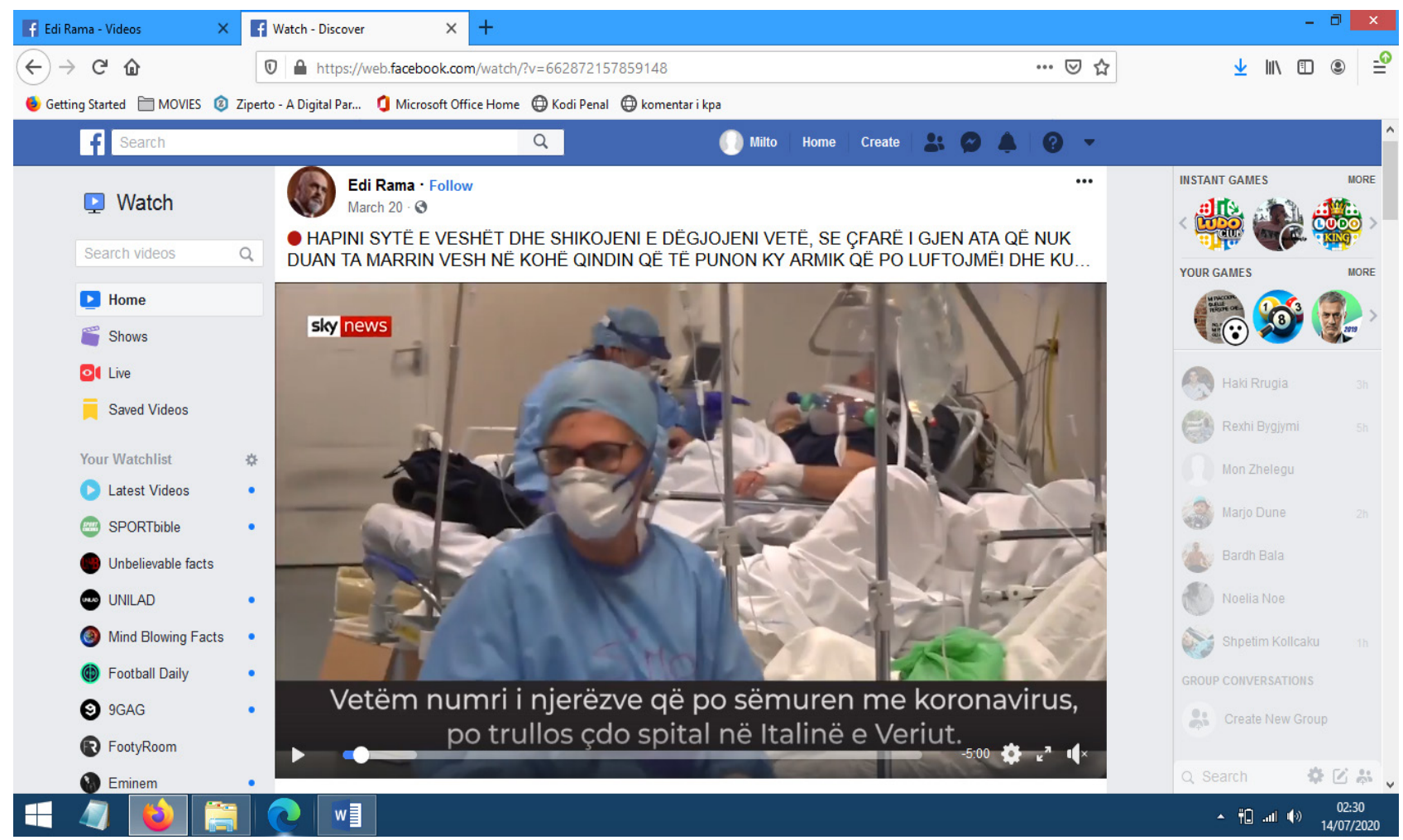

\section{VIDEO 05:10 minuta41K likes 3.9K Comments12K Shares 2.4M Views}

Edi Rama në postimet e tij ruan një stil komunikues spontan, stil i përpunuar më pare nga ekspertët e tij të Marrëdhënieve me Publikun dhe që shfaqet në formën e replikimeve që ai bën me komentuesit e tij 
Arta Sakja

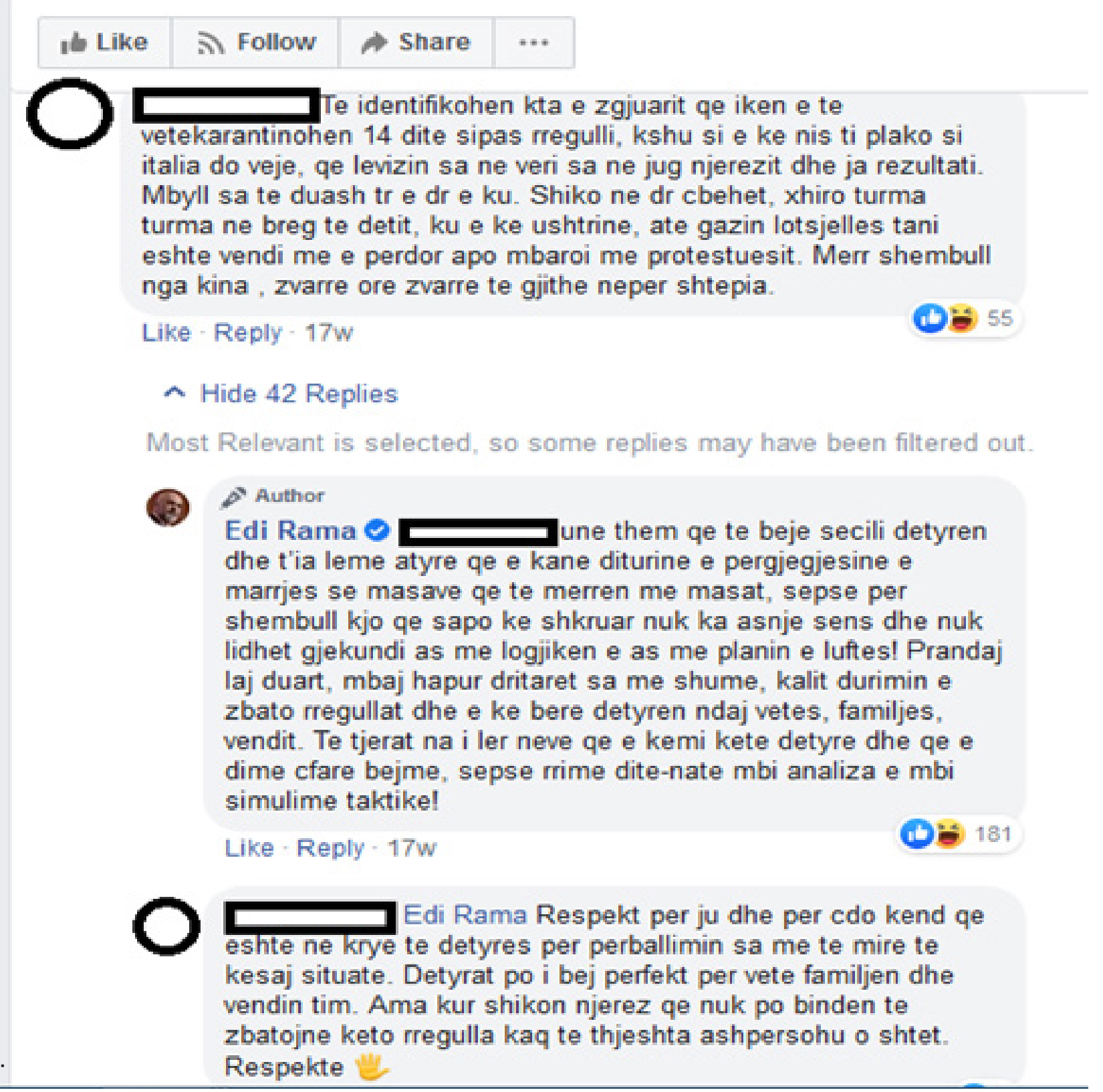

Shumica e postimeve të profilit zyrtar në Facebook Kryeministrit Edi Rama përbëhen nga video apo foto ilustruese. Mbizotëron përdorimi i videove live, më saktësisht 145 të tilla nga 355 postime në total, ku është përdorur opsioni i live në Facebook nga profili i Kryeministrit edhe për konferencat për shtyp të anëtarëve të ndryshëm të kabinetit qeveritar dhe institucioneve publike si psh: Ogerta Manastirliu, Ministre e Shëndetësisë dhe Mbrojtjes Sociale, Eugena Tomini, Instituti i Shëndetit Publik, Zv.Ministre e Shëndetësisë dhe Mbrojtjes Sociale Mira Rakacolli dhe Përgjegjësja e Departamentit të Sëmundjeve Infektive në Institutin e Shëndetit Publik, Silva Bino. 
KOMUNIKIMI PUBLIK NË PERIUDHËN E KARANTINIMIT NË SHQIPËRI SI KOMUNIKIM NË KRIZË

\section{MARS 4:00 PM.}

Edi Rama was live.

ITALIA ËSHTË SHTËPIA JONËALIT SOT JEMI TË GJITHË ITALIANË

ITALIA E CASA NOSTRAALITOGGI SIAMO TUTTI ITALIANI

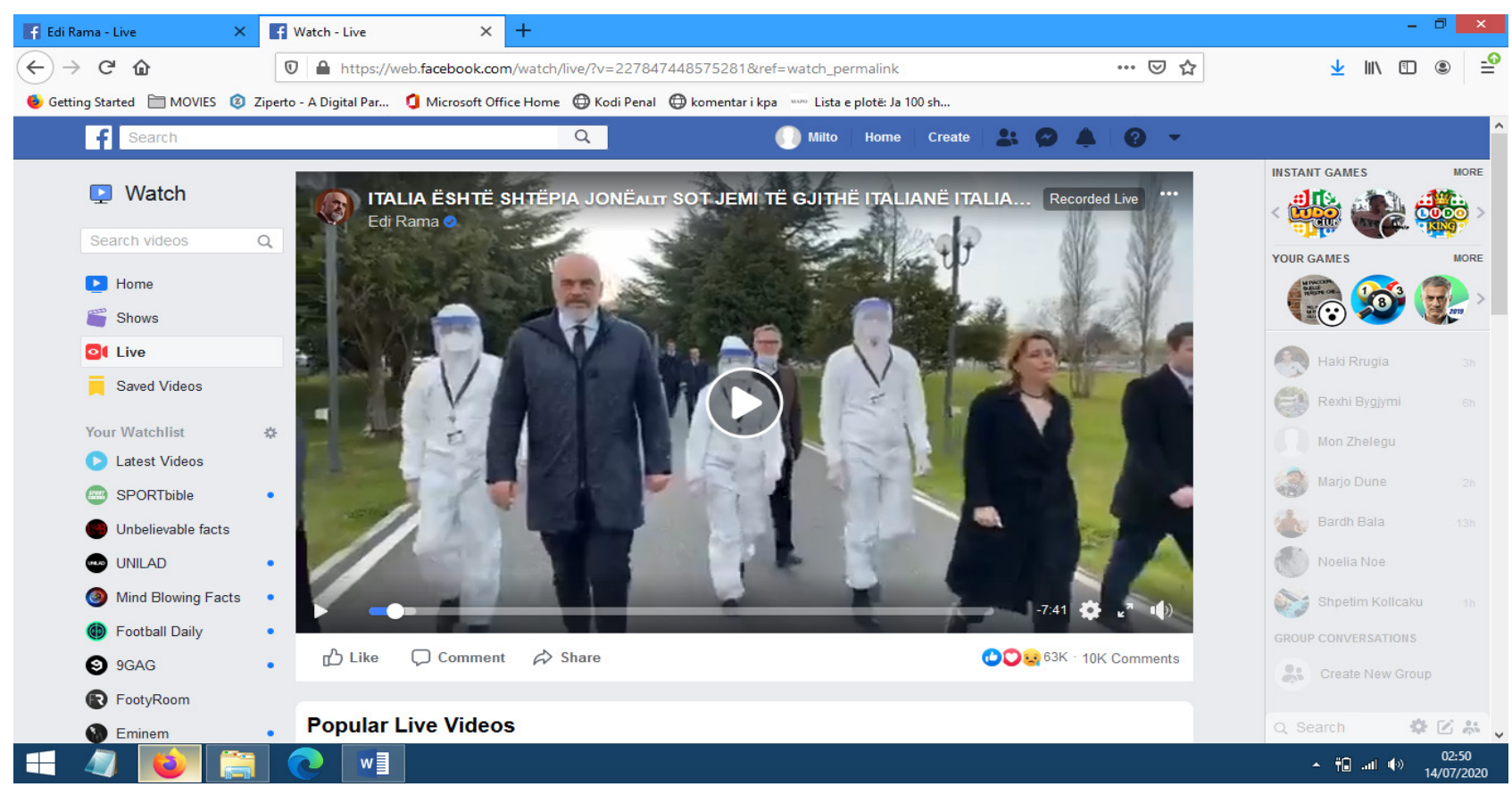

\section{VIDEO 08:01 minuta 63K likes 10K Comments 11K Shares 1.4M Views}

Postimi i mësipërm është më i pëlqyeri gjatë periudhës së vëzhgimit, me 63 mije like,

Është një video e regjistruar live në aeroportin Nënë Tereza, ku rreth 30 mjekë dhe infermierë shqiptarë do të udhëtonin drejt Italisë për tu ofruar si vullnetarë në spitalet ku trajtoheshin pacientët e infektuar me Covid-19. Siç shikojmë shpesh në video të tjera live gjatë periudhës së pandemisë ku ndërmerren vendime të rëndësishme hapësirën më të madhe të filmimit e zë Kryeministri Rama, ndërsa stafi mjekësor vullnetar dhe persona të tjerë publikë si përshembull ministra shfaqen në plan të dytë.

Detaje të tjera të vogla por të rëndësishme të postimeve të Kryeministrit Rama janë përdorimi i figurave emoji,( figura dixhitale që përdoren për të shprehur një emocion apo një mendim të caktuar në biseda informale) shprehje popullore dhe një komunikim joformal, një fenomen i rrallë në profilin zyrtar të një politikani, 
Arta Sakja

\section{MARS 8:19 PM •}

Edi Rama

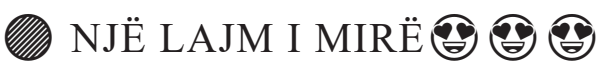

KONTAKTI I PARË I PACIENTIT ZERO QË KUROHET NË SPITALIN INFEKTIV DOLI NEGATIV NË TESTIN E PARË

NËSE EDHE NË TESTIN E DYTË PAS 48 ORËSH KY REZULTAT DO TË KONFIRMOHET, ATËHERË DO TË KEMI TË SHËRUARIN E PARË凸冒

Q TË PRESIM DHE TË LUTEMI QË ZOTI T'U JAPË FORCË TË SËMURËVE DHE HERONJVE ME BLUZA TË BARDHA, NË VIJËN E ZJARRIT ME ARMIKUN

DURIM, BESIM DHE DURIM, DURIM, DURIM!

\section{LO $\bigcirc E$ YOU}

\section{K likes 1.7K Comments 583 Shares}

Të gjitha këto elemente duken të përdorura qëllimisht për të rritur shkallën e popullaritetit të tij duke ndjekur një trend komunikimi të përdorur nga të rinjtë.

\section{Lulzim Basha në facebook ${ }^{10}$}

- Ai bëri gjithsej 61 postime në profilin e tij zyrtar në Facebook përgjatë kësaj periudhe.

- Mesatarisht bëri 2 postime në ditë.

- Shfrytëzoi videot në 6 raste.

- Shfrytëzoi videot live në $\mathbf{2 6}$ raste.

- Shfrytëzoi fotografinë në $\mathbf{2 4}$ raste.

- Një postim i tij mori mesatarisht 3600 pelqime. (like)

- Postimet e tij u shpërndanë mesatarisht 390 herë. (share)

-Mesatarisht një postim i tij pati 455 komente.

Analizë :

Nëse do të ndërtonim një profil të Lulzim Bashës në komunikimin publik gjatë pandemisë do të shikojmë kryetarin tipik të opozitës, që i ofron qytetarëve zgjidhje të ndryshme të problematikave të shumta të hasura gjatë pandemisë nga ato të ndërmarra nga qeverisja.

\section{March 21 at 11:38 AM .}

Kjo nuk është aspak mirë! Kjo është shumë e rrezikshme!

Natyrisht që njerëzit duhet të blejnë gjërat e domosdoshme, duhet të marrin shërbimet esenciale, ju duhet të kryejnë disa pagesa, por grumbullime si këto janë të rrezikshme. Kjo është mënyrë e sigurtë për të përhapur virusin. Të tilla grumbullime zhvlerësojnë çdo sakrificë të bërë deri tani. 
KOMUNIKIMI PUBLIK NË PERIUDHËN E KARANTINIMIT NË SHQIPËRI SI KOMUNIKIM NË KRIZË

Ndaj duhet një analizë objektive, bazuar mbi praktikat më efektive deri tani: Si mund të organizohet dhe zbatohet izolimi dhe distancimi sa më $i$ disiplinuar dhe nga ana tjetër njerëzit të mund të marrin shërbimet jetike POR duke shmangur çdo dalje të panevojshme, radhët e gjata dhe grumbullimet masive. Asgjë nuk është e lehtë. Por gjithçka duhet bërë që të shmangim dhe ngadalësojmë sa mundemi përhapjen e COVID 19.

Të dashur qytetarë! Qëndroni në shtëpi! Duke respektuar distancimin social, izolojmë virusin. Kështu i japim shans vetes dhe të afërmve tanë ta kalojmë me sa më pak pasoja këtë gjendje dhe t'i rikthehemi sa më parë normalitetit!"

Postimet e tij në media sociale janë të kufizuara vetëm tek çështjet që i duken më të spikatura.

Ashtu si edhe në rastin e profilit të Edi Ramës, postimet më të shpeshta janë ato të shoqëruara me foto ose video, më saktësisht 56 postime të tilla nga 61 gjithsej.

\section{MARS 5:00 PM •}

Lulzim Basha was live.

LIVE - Nga selia e PD në News 24

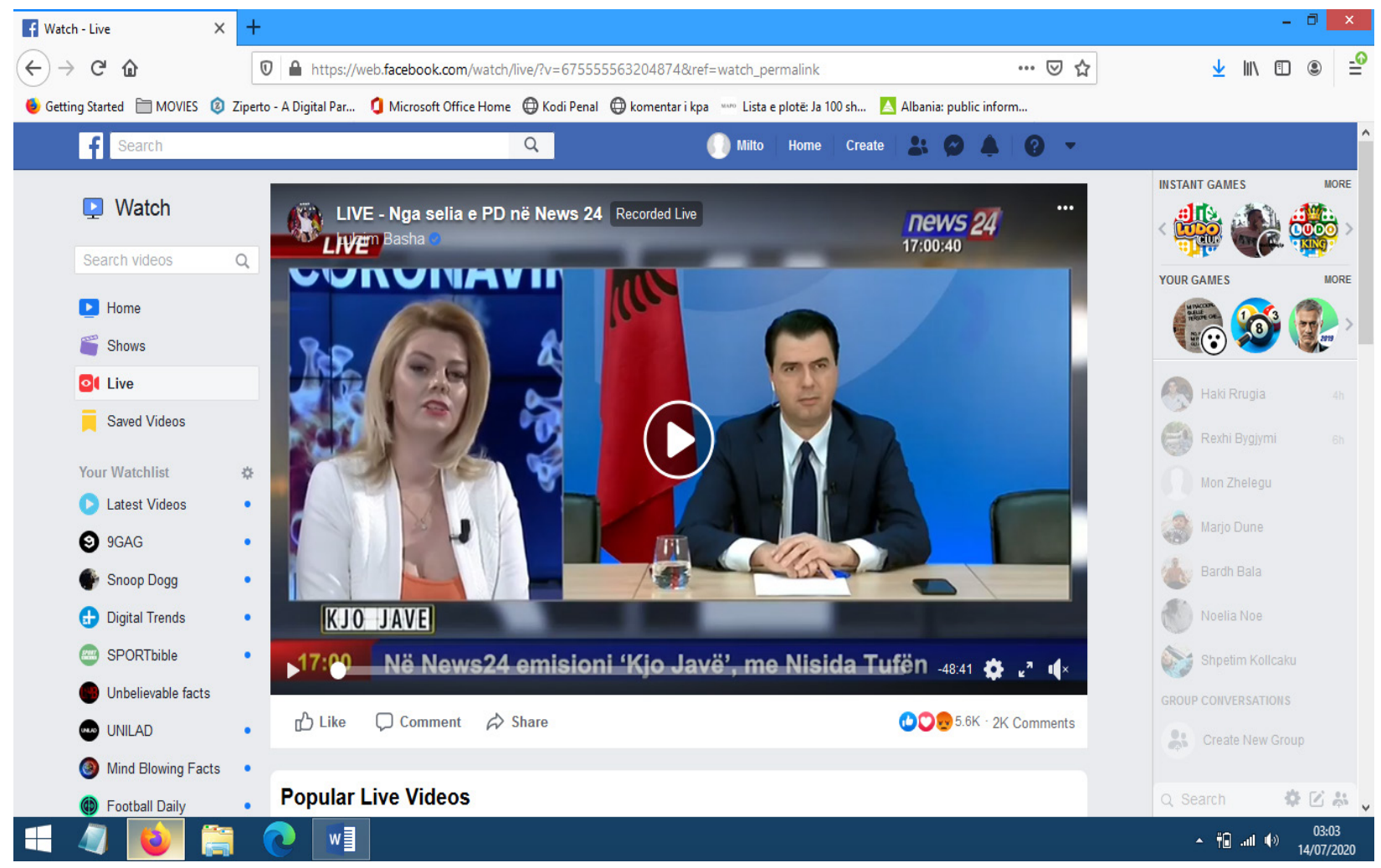

VIDEO 48:45 minuta 5.6K likes 2K Comments 1.2K Shares 241K Views 
Arta Sakja

Video është një regjistrim live prej rreth 50 minutash ku kryetari i opozitës është i ftuar në intervistë online në emisionin "Kjo Jave” të televizionit News24 me moderatore Nisida Tufën. Ky është një shembull tipik sesi opsioni video live i Facebook shfrytëzohet njëkohësisht me Live-in e emisioneve televizive me qëllim për të zgjeruar audiencën në të dyja frontet.

Karakteristikë e postimeve të Lulzim Bashës në Facebook janë shkrimet e gjata dhe të detajuara si në rastet e planeve ekonomike të propozuara ose denoncimin e problematikave të hasura gjatë pandemisë.

\section{MARS 5:24 PM .}

Nisur nga rasti i fundit, ku fatkeqësisht, edhe një mjek i spitalit të Durrësit rezulton mes të prekurve nga Covid-19, u bëj thirrje qytetarëve të tregohen maksimalisht bashkëpunues me stafet mjekësore. Të tregojnë në mënyrë të detajuar shqetësimin e tyre, historikun e udhëtimeve apo kontaktin që mund të kenë pasur me persona të prekur nga Covid 19.

Në këtë mënyrë do të ndihmoni veten dhe nuk do të rrezikoni shëndetin e mjekëve, të cilët janë mburoja jonë, mburoja e çdo qytetari në këtë situatë.

Mos neglizhoni asnjë detaj!

I bëj thirrje qeverisë të marrë masa të menjëhershme për personelin shëndetësor parësor. Ata janë të ekspozuar ndaj personave mbartës potencialë të Covid 19, por që, për shkak të shenjave joshqetësuese, mund ta neglizhojnë këtë fakt e të drejtohen tek qendrat shëndetësore apo spitalet rajonale. Autoritetet duhet të pajisin të gjithë personelin e dedikuar për raste të tilla me veshjet dhe mjetet e posaçme mbrojtëse.

Përhapja e virusit, zgjerimi $i$ vatrave të tij është një rrezik potencial, të cilit $i$ duhet paraprirë.

Thirrja ime është për të gjithë qytetarët: E di që shumë prej jush nuk janë mësuar të rrinë mbyllur apo kanë kushte jo të përshtatshme. Shumë të tjerë kanë nevojë të punojnë për të çuar bukën e përditshme në shtëpi, por asgjë nuk vlen më shumë sesa jeta.

Me qëndrimin në shtëpi mbroni veten, familjen, miqtë dhe të afërmit. Nga sakrificat e sotme varet jeta, shëndeti, e sotmja dhe e nesërmja jonë. Mbi të gjitha, duke kontribuar në mospërhapjen e shpejtë të virusit, ne bëjmë pjesën tonë si qytetarë për ruajtjen e sistemit shëndetësor nga kolapsi.

Sa më të pakujdesshëm sot, aq më shumë do të zgjasë kjo situatë, e cila ka pasoja të drejtpërdrejta në shëndetin dhe në ekonominë e secilit prej nesh.

Kjo është një kohë për kujdes shëndetësor, por edhe për kujdes social për ata më të pamundurit.

I bëj thirrje qeverisë të marrë të gjitha masat për t'u mundësuar familjeve në nevojë dhe në pamundësi gjërat më të domosdoshme për të kaluar këtë krizë dhe për të ruajtur shëndetin 
duke mundësuar që asnjë familje mos të mbetet pa ushqim dhe mjete higjenike.

Ju bëj thirrje kompanive celulare të sigurojnë akses pa pagesë në internet për fëmijët dhe studentët që në javët në vazhdim do të zhvillojnë online procesin mësimor. Ky kontribut për mësimin online të fëmijëve, do të ishte shumë $i$ çmuar dhe $i$ vlerësuar!
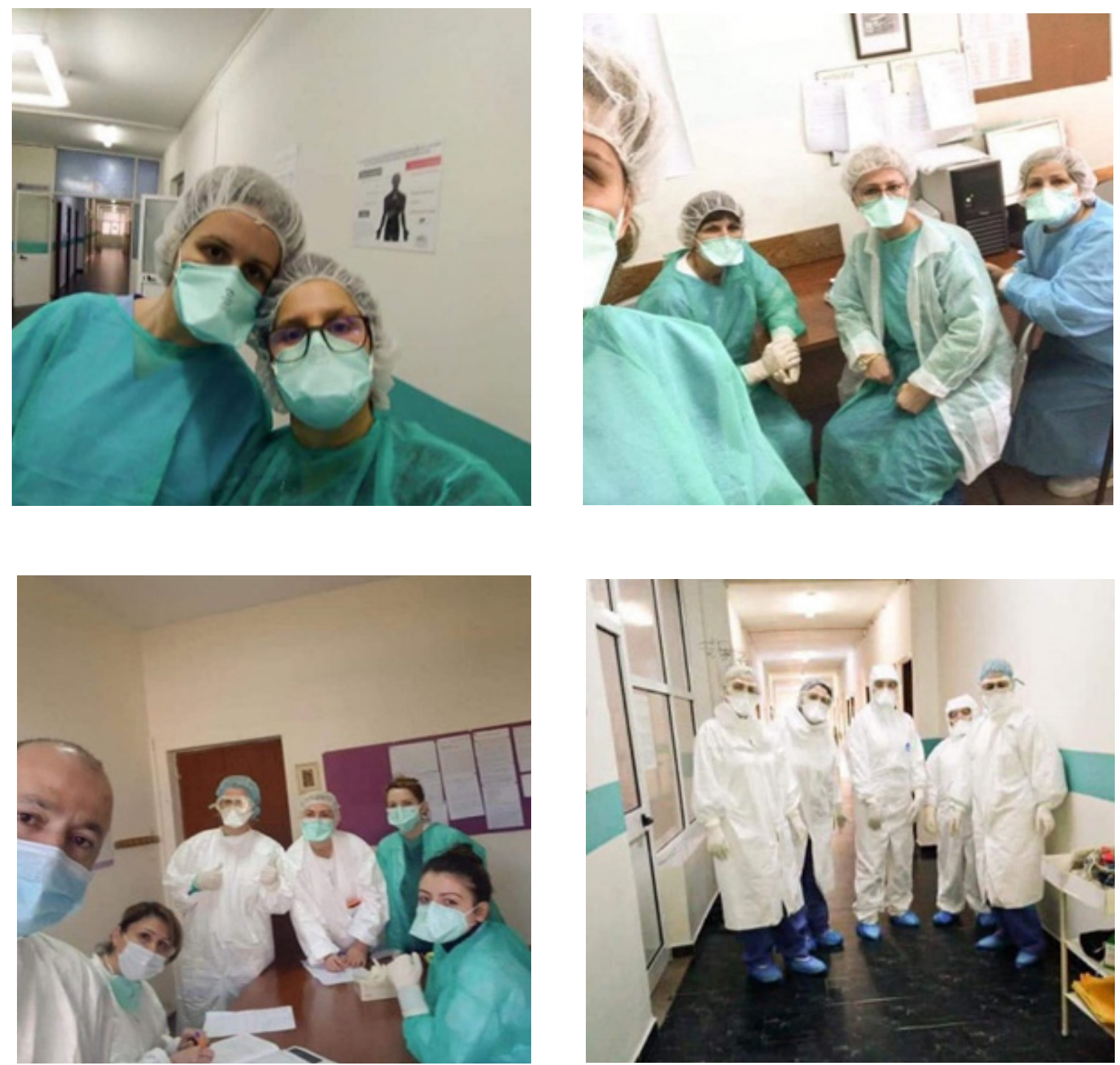

\section{K likes 255 Comments 374 Shares}

Ndryshe nga stili i Kryeministrit, stili komunikues i përdorur nga ai është më formal dhe fjalët janë më të zgjedhura.

Eviton tërësisht përdorimin e figurave emoji dhe hashtagëve, duke ruajtur gjithmonë imazhin e politikanit ndryshe nga ai përballë tij. 
Arta Sakja

Asnjëherë nuk shikohet ndonjë rast bashkëveprimi me komentuesit në postimet e tij, qoftë kur has kritika apo lavdërime, duke mos krijuar kështu bashkëveprim me komentuesit.

\section{V.Përfundimet :}

- Politika shqiptare e shfrytëzoi gjerësisht median sociale për të komunikuar me publikun e gjerë.

- Ajo preferoi komunikimin nëpërmjet medias sociale duke shfrytëzuar shpejtësinë e përhapjes së informacionit dhe numrin e lartë të përdoruesve në Shqipëri.

- Rrjeti social më i përdorur është Facebook. Twitter u përdor si rrjet i dytë por aty politikanët shqiptarë nuk patën sukses, pasi ndjekësit ishin shumë të paktë në numër.(1.52\% është penetrimi i tij sipas Social Media Stats Albania).

Profilet në Instagram të lidërve politikë shërbyen si pasqyrë apo kopje e postimeve të publikuara në Facebook. (Përdorimi i tij në Shqipëri sipas Social Media Stats Albania është $0.8 \%$.)

- Risi ishte përdorimi i opsionit të videos LIVE në Facebook të të dy liderëve kryesore politikë. Shumë shpesh përdorimin e videos live e hasim gjatë konferencave të ndryshme për shtypin apo intervista në emisione televizive, duke zgjeruar kështu audiencën në dy nivele: audiencën online dhe audiencën në TV.

Qëndrimet e tyre shpesh ishin të kuruara dhe të ideuara për të përmirësuar imazhet respektive institucionale.

- Ata mbajtën qëndrimet klasike të mazhorancës apo të opozitës përgjatë çdo postimi të tyre. Mazhoranca preferoi të mbajë pozitat e shtetit të fortë dhe autoritar që vendos rregull. Lideri i mazhorancës tregoi forcën e shtetit shpesh në mënyrë të ekzagjeruar duke postuar në Facebook video nga ambiente spitalore me pacientë që trajtoheshin nga Covid-19 apo duke shpërndarë fotografi e video të forcave ushtarake dhe policore me qëllim karantinimin e plotë të popullsisë.

-Lideri i opozitës u përqëndrua tek këshillat për ruajtjen e shendetit, masat e pamarra nga qeveria në mbrojtjen e jetës së stafit mjekësor dhe mosrespektimin e karantinës në biznese të ndryshme si fasoneritë apo call center. Ai gjithashtu u përpoq të tregojë dëmet qe po i shkaktonte ekonomisë karantinimi i zgjatur duke kontaktuar qytetarë e biznese që nuk merrnin bonusin e premtuar nga qeveria duke mbajtur kështu një qasje tipike opozitare.

- Si përfundim, mund të themi që të dy vepruan në kushtet e krizës pa strategji, por me taktika momentale, me qëllimin kryesor të rritjes së imazhit publik respektiv si përfaqësuesit qendrorë të pozitës apo opozitës. 
KOMUNIKIMI PUBLIK NË PERIUDHËN E KARANTINIMIT NË SHQIPËRI SI KOMUNIKIM NË KRIZË

\section{Referenca}

1.https://al.ejo-online.eu/media-dhe-politika/vleresimi-dhe-ndikimi-i-internetit-e-rrjeteve-sociale-ne-politiken-shqiptare.

2. https://www.internetworldstats.com/europa2.htm

3. Pierre Zémor, La communication publique, Presses Universitaires de France, 2008. pg 25.

4. Brian MC Nair: (2011) An introduction to political communication, Routledge, London, pg.4.

5. Gianpietro Mazzoleni, La comunicazione politica, 2012, pg.8 .

6. Jacques Gerslté, La communication politique, Armand Collin, 2020, pg. 3.

7. Jacques Gerstlé., Reseaux de communication, reseaux sociaux et reseaux politiques" in Musso P( dir) Critique des reseaux, PUF.

8. Xavier Manga, La communication de crise à l'ère des médias socionumériques, Presses de 1'Université du Québec, 2018, pg 135.

9. https://www.facebook.com > edirama.al

10. https://www.facebook.com > lulzimbasha.al 